\title{
ANALISIS PEMASARAN IKAN DALAM MENINGKATKAN PENDAPATAN NELAYAN DI KABUPATEN BENGKALIS (TINJAUAN PERSPEKTIF EKONOMI ISLAM)
}

\author{
Susilawati \\ Sekolah Tinggi Ilmu Ekonomi (STIE) Syariah Bengkalis \\ Email: susilawatirasip92@gmail.com
}

\begin{abstract}
ABSTRAK
Penelitian ini bertujuan untuk menganalisis: (1) Mengidentifikasi kondisi internal dan eksternal dalam menjalankan kegiatan pemasaran ikan di Kabupaten Bengkalis, (2) Saluran distribusi pemasaran yang ditempuh oleh nelayan di Kabupaten Bengkalis, (3) Tinjauan perspektif ekonomi Islam terhadap pemasaran ikan yang dilakukan oleh nelayan di Kabupaten Bengkalis. Penelitian ini termasuk jenis penelitian lapangan dengan metode kualitatif. Populasi dan sampel penelitian adalah nelayan yang ada di Kabupaten Bengkalis dengan jumlah populasi sebesar 2986 orang pada tahun 2015 diperkecil dengan rumus Solvin sehingga jumlah sampel menjadi 97 orang. Teknik pengumpulan data melalui observasi, pembagian angket (koesioner), wawancara, dan dokumentasi. Hasil penelitian menunjukan bahwa Faktor Internal meliputi; kekuatan dan kelemahan. a. Kekuatan yaitu, Kemampuan hasil produksi perikanan yang cukup besar, Melimpahnya sumberdaya kelautan dan perikanan, dan letak wilayah yang strategis. b. kelemahan yaitu, produksi hasil tangkapan yang tidak menentu, harga yang tidak setabil, kelembagaan TPI (tempat pendaratan ikan) yang tidak berfungsi, dan lemahnya pengetahuan pemasaran. Dan faktor eksternal meliputi peluang dan ancaman; a. Peluang yaitu, produksi hasil tangkapan yang bervariasi, wilayah pemasaran yang luas, dan kualitas hasil tangkapan yang segar. b. Ancaman yaitu, produksi hasil tangkapan yang mudah rusak, penetapan harga secara sepihak, pengetahuan masyarakat tentang harga yang masih rendah, dan perkembangan teknologi dalam pemasaran yang masih minim. Saluran distribusi pemasaran ikan yang ditempuh nelayan Kabupaten Bengkalis adalah 1) Nelayan memasarkan langsung kepada Konsumen; 2) Nelayan memasarkan langsung kepada pedagang pengumpul untuk kemudian dipasarkan kembali kepada pedagang pengecer maupun konsumen akhir; 3) Nelayan memasarkan langsung kepada pedagang pengecer untuk kemudian didistribusikan kepada konsumen akhir. Ditinjau dari perspektif ekonomi Islam, pemasaran ikan yang terjadi di Kabupaten Bengkalis dalam kegiatan pemasaran harus berlandaskan nilai-nilai Islam berkaitan dengan kualitas dan keberadaan barang, penetapan harga barang, tempat distribusi barang, serta promosi barang yang terhindar dari adanya unsur garar, Ikhtikar, menzolimi, terzolimi dan unsur riba dalam aktivitas pemasaran.
\end{abstract}

Kata Kunci: Pemasaran, Pendapatan, Ekonomi Islam.

\section{PENDAHULUAN}

Indonesia sebagai suatu Negara Kepulauan dengan penduduk pantai yang besar jumlahnya, serta begitu luasnya wilayah pantai Indonesia menjadi alasan 
yang kuat bagi penduduk Indonesia sendiri secara maksimal memanfaatkan kekayaan laut yang ada di setiap wilayah kepulauannya. Kekayaan berupa Sumber daya hayati yang terdapat di dalam laut tersebut sangat beragam mulai dari berbagai jenis ikan yang kaya protein, terumbu karang, aneka bahan tambang, dan banyak lagi.

Islam menganjurkan agar manusia memanfaatkan potensi dirinya (sumber daya manusia) dalam memanfaatkan sumber daya alam baik didarat maupun dilaut yang tercantum pada firman Allah dalam Al-Quran surah An-Nahl Ayat 14 berikut ini:

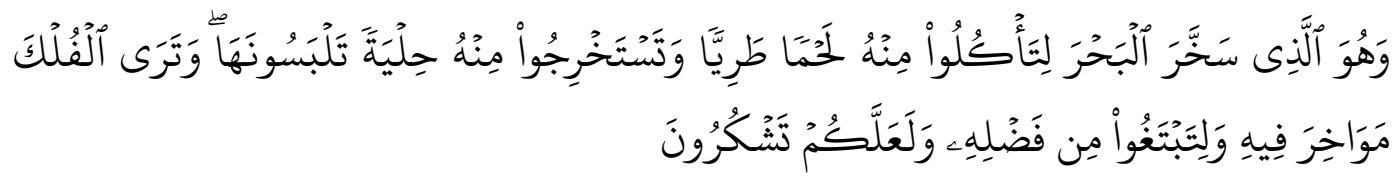

Artinya: "Dan Dia-lah, Allah yang menundukkan lautan (untukmu), agar kamu dapat memakan daripadanya daging yang segar (ikan), dan kamu mengeluarkan dari lautan itu perhiasan yang kamu pakai; dan kamu melihat bahtera berlayar padanya, dan supaya kamu mencari (keuntungan) dari karunia-Nya, dan supaya kamu bersyukur”. (QS. An-Nahl (16): 14)

Perikanan telah menjadi bagian yang tidak terpisahkan dari sejarah peradaban manusia. Perikanan tidak saja mengubah pola peradaban tetapi, juga telah mengubah pola pemanfaatan sumber daya ikan dari sekedar kebutuhan pangan menjadi cara hidup (way of life) dan juga kebutuhan ekonomi (Fauzi 2010, 2).

Sektor perikanan mempunyai peran dalam perekonomian yang bisa dilihat berdasarkan kontribusinya terhadap lapangan pekerjaan. Perikanan baik secara langsung maupun tidak langsung memainkan peranan penting bagi jutaan orang yang bergantung hidupnya pada sektor perikanan. Indonesia sendiri sebagian besar masyarakat di daerah pesisir sangat bergantung hidupnya dari sektor perikanan sehingga tidaklah mengherankan jika sektor perikanan sering disebut sebagai "employment of the last resort" di mana tenaga kerja yang tidak terserap pada sektor lain akan mudah diserap oleh sektor perikanan. (Fauzi 2010, 9)

Kelompok masyarakat yang memanfaatkan sumber daya perikanan adalah masyarakat nelayan. Masyarakat nelayan merupakan kelompok masyarakat yang melakukan aktivitas usaha dengan mendapat penghasilan bersumber dari kegiatan menangkap ikan. Semakin banyak maka semakin besar pula pendapatan yang diterima dan pendapatan tersebut sebagian besar untuk keperluan konsumsi keluarga. Dengan demikian tingkat pemenuhan kebutuhan konsumsi keluarga ditentukan oleh pendapatan yang diterimanya. Sumber daya perikanan sebenarnya secara potensial dapat dimanfaatkan untuk meningkatkan taraf hidup dan kesejahteraan nelayan, namun pada kenyataannya masih banyak nelayan belum dapat meningkatkan hasil tangkapannya, sehingga tingkat pendapatan nelayantidak meningkat. (Sujarno 2008)

Kabupaten Bengkalis merupakan salah satu wilayah yang yang memiliki potensi perikanan dan kelautan yang cukup besar di Provinsi Riau. Besarnya potensi sumber daya perikanan yang dimiliki oleh kabupaten Bengkalis dapat dimaklumi, karena letak geografis cukup strategis. Namun pendapatan masyarakat nelayan yang ada di Kabupaten Bengkalis masih 
tergolong berpendapatan sedang dikarenakan hasil perikanan tangkap dipengaruhi oleh cuaca atau musim.

Fenomena yang dihadapi nelayan pada saat ini bukan hanya tentang besarnya potensi ikan yang ada di Kabupaten Bengaklis melainkan pada permasalahan pemasaran hasil tangkapan nelayan. Pada kenyataannya kegiatan pemasran ikan seharusnya melalui tempat pendaratan ikan (TPI) yang berperan aktif dalam menyalurkan hasil tangkapan nelayan sehingga nelayan memperoleh pendapatan yang dapat memenuhi kebutuhan hidup sehingga bisa dikatakan bahwa nelayan tersebut sejahtera.

Pemasaran ikan di kabupaten Bengkalis pada kenyataannya tidak melalui tempat pendaratan ikan (TPI) yang mana berfungsi sebagai pendorong pertumbuhan kegiatan usaha perikanan salah satunya adalah dalam segi pemasaran. Banyak tempat pendaratan ikan (TPI) yang tidak difungsikan karena sebagian besar ikan dijual oleh nelayan kepada pedagang pengumpul di luar TPI.

Pemasaran akan berpengaruh besar terhadap pendapatan nelayan mengingat sifat hasil perikanan yang mudah rusak. Jika kualitas hasil laut menurun akibat saluran distribusi pemasaran yang kurang baik, maka harga jualnya akan turun sehingga pendapatan nelayan berkurang. Jika ikan sudah tidak segar, tengkulak tidak mau membelinya sehingga ikan tidak laku. Oleh karena itu perlu dilakukan suatu penelitian mengenai pemasaran ikan dalam meningkatkan pendapatan nelayan.

Pemasaran merupakan bagaian dari perniagaan. Perniagaan merupakan salah satu mata pencaharian yang terpuji didalam Islam, bahkan merupakan salah satu mata pencaharian yang paling utama (Arifin 2008, 35). Pemasaran syariah merupakan salah satu bentuk muamalah yang dibenarkan dalam Islam, sepanjang dalam segala proses transaksinya terpeleihara dari hal-hal yang terlarang oleh ketentuan Syariah

\section{TELAAH PUSTAKA}

\section{Pemasaran}

Istilah pemasaran diartikan sama dengan tataniaga atau distribusi, yaitu suatu macam kegiatan ekonomi yang berfungsi membawa atau menyampaikan barang dari produsen ke konsumen (Mubyarto 1995, 166).

\section{Pemasaran dalam Islam}

Pemasaran dalam pandangan Islam merupakan suatu penerapan disiplin strategis yang sesuai dengan nilai dan prinsip syariah. Ide mengenai Pemasaran Syariah ini sendiri ditelurkan oleh dua orang pakar di bidang Pemasaran dan Syariah. Salah satu dari lima puluh orang guru yang telah mengubah masa depan dunia pemasaran bersama-sama dengan Philip Kotler, dan Muhammad Syakir Sula, salah satu dari enam pemegang gelar profesional ahli Asuransi Syariah juga CEO Batasa Tazkia sebuah Konsultan Syariah yang cukup dikenal dikalangan perbankan dan Asuransi Syariah.

Mereka memberikan definisi untuk Pemasaran Syariah (Marketing Syariah), adalah sebagai berikut: Sharia Marketing is a strategic business discipline that directs the process of creating, offering, and changing value 
from one initiator to its stakeholders, and the whole process should be in aaccordance with muamalah principles in Islam (Kartajaya 2006, 26-27).

Pengertian dari Sharia Marketing di atas jika diterjemahkan adalah sebagai berikut; Marketing Syariah adalah sebuah disiplin strategis yang mengarahkan proses penciptaan, penawaran, dan perubahan values dari satu inisiator kepada stakeholder-nya, yang dalam keseluruhan prosesnya sesuai dengan akad dan prinsip-prinsip muamalah Islami.

\section{Pendapatan}

Pendapatan dalam ilmu ekonomi teoritis adalah hasil yang diterima, baik berupa uang maupun lainnya atas penggunaan kekayaan (jasa manusia) (Ridwan, 2004, 33). Dijelaskan pula bahwa pendapatan adalah hasil dari penjualan faktor-faktor produksi yang dimilikinya kepada sektor produksi. Selain itu pendapatan adalah pendapatan uang yang diterima dan diberikan kepada subjek ekonomi berdasarkan prestasi-prestasi yang diserahkan yaitu berupa pendapatan dari profesi yang dilakukan sendiri atau usaha perorangan dan pendapatan dari kekayaan. Besarnya pendapatan seseorang bergantung pada jenis pekerjaannya (Anwar, 2011).

\section{METODOLOGI PENELITIAN}

\section{Lokasi dan Waktu Penelitian}

Lokasi dan Adapun tempat penelitian yang akan dilakukan adalah di Kabupaten Bengkalis yang wilayah penelitian mencakup 4 (empat) Kecamatan yaitu, Kecamatan Bengkalis, Kecamatan Bantan, Kecamatan Rupat, dan Kecamatan Rupat Utara. Penelitian ini dilakukan mulai tanggal 18 Januari 2017 sampai dengan 18 April 2017.

\section{Jenis dan Sumber Data}

Jenis data yang dikumpulkan adalah data prime dan data skunder. Data primer, yaitu data yang diperoleh sendiri oleh peneliti secara langsung dari sumber pertama atau tempat objek penelitian dilakukan. Data yang dianalisis adalah data tentang pendapatan nelayan tangkap. Proses untuk memperoleh data primer ini dengan menggunakan teknik observasi dan wawancara langsung dengan pihak responden yaitu nelayan serta menggunakan angket (kuesioner). Nelayan sebagai responden dalam penelitian ini diperoleh di kecamatan Bengkalis, kecamatan Bantan, kecamatan Rupat dan kecamatan Rupat Utara. Data sekunder yaitu data penunjang hasil penelitian berbentuk data-data dokumentasi lainnya yang dapat memperkuat data hasil penelitian, perizinan dan lokasi tangkap dari dinas Keluatan dan Perikanan serta data-data yang berasal dari BPS Kabupaten Bengkalis, instansi terkait dan sumber-sumber data dari internet.

\section{Metode Analisa Data}

Data yang terkumpul akan dianalisa dengan menggunakan metode analisis berikut: 


\section{a. Deskriptif}

Statistik deskriptif adalah statistik yang digunakan untuk menganalisa data dengan cara mendiskripsikan atau menggambarkan data yang telah terkumpul sebagaimana adanya tanpa bermaksud membuat kesimpulan yang berlaku untuk umum atau generalisasi (Sugiyono 2002). Metode analisis deskriptif kualitatif ini dimaksudkan untuk memaparkan pemasaran ikan dalam meningkatkan pendapatan nelayan di Kabupaten Bengkalis.

Tujuan dari metode ini adalah untuk membuat deskripsi atau gambaran mengenai objek penelitian secara sistematis, faktual dan akurat mengenai fakta-fakta, sifat-sifat serta hubungan antara fenomena yang diselidiki.

\section{b. Pola Pikir Induktif}

Untuk menarik kesimpulan secara benar, maka digunakan pola pikir induktif, yaitu proses pendekatan yang berangkat dari kebenaran umum mengenai materi suatu teori dan menggeneralisasikan kebenaran tersebut pada suatu peristiwa atau data tertentu yang berciri sama dengan fenomena yang bersangkutan. Kemudian data tersebut diolah dan dianalisa dengan pola pikir induktif, yakni bermula dari pemasaran ikan, pendapatan nelayan setelah melakukan pemasaran dan langkah-langkah pemerintah dalam mengatur pemasaran sehingga dapat meningkat pendapatan nelayan.

\section{c. Analisis Deskriptif kualitatif}

Analisis data saluran pemasaran ikan masyarakat nelayan di Kabupaten Bengkalis dilakukan dengan pendekatan deskriptif kualitatif. Analisis deskriptif kualitatif merupakan metode analisis yang digunakan dengan tujuan untuk memperoleh gambaran secara mendalam dan obyektif mengenai obyek penelitian serta tidak melakukan analisis hubungan diantaranya.

\section{d. Analisis SWOT}

SWOT adalah akronim untuk kekuatan (Strenghts), kelemahan (Weakness), peluang (Opportunities), dan ancaman (Threats) dari lingkungan eksternal perusahaan. SWOT digunakan untuk menilai kekuatan-kekuatan dan kelemahan-kelemahan dari sumber-sumber daya yang dimiliki perusahaan dan kesempatan-kesempatan eksternal dan tantangan-tantangan yang dihadapi. Kekuatan/kelemahan internal, digabungkan dengan peluang/ancaman dari eksternal dan pernyataan misi yang jelas, menjadi dasar untuk penetapan tujuan dan strategi. Tujuan dan strategi ditetapkan dengan maksud memanfaatkan kekuatan internal dan mengatasi kelemahan.

\section{HASIL DAN PEMBAHASAN PENELITIAN}

\section{Faktor-Faktor Internal Dan Eksternal Dalam Kegiatan Pemasaran Ikan Oleh Nelayan Di Kabupaten Bengkalis}

Pemasaran adalah sistem keseluruhan dari kegiatan usaha yang ditujukan untuk merencanakan, menentukan harga, mempromosikan dan mendistribusikan barang dan jasa yang dapat memuaskan kebutuhan pembeli (Stanton 1996, 7). 
Dalam menjalankan kegiatan pemasaran dan kebijakan-kebijakan yang telah dirumuskan pastilah tidak selalu sesuai dengan apa yang diharapkan. Di sisi lain pasti selalu ada masalah yang harus dihadapi. Hal demikian terdapat pada kegiatan pemasaran ikan oleh nelayan yang ada di Kabupaten Bengkalis.

Faktor internal dan faktor eksternal dalam kegiatan pemasaran yang diperoleh dilapangan tersebut akan dianalisa dalam tabel SWOT yang merupakan faktor internal yang meliputi Strengths (Kekuatan), Weaknesses (Kelemahan), dan faktor eksternal yang ,meliputi Oportunities, (Peluang) dan Threats (Ancaman).

Adapun secara keseluruhan kegiatan pemasaran yang diperoleh dilapangan tersebut dapat dilihat dalam tabel SWOT di bawah ini, antara lain sebagai berikut:

Tabel 1

Analisa SWOT Internal Dan Eksternal Kegiatan Pemasaran Ikan Di Kabupaten Bengkalis

\begin{tabular}{|c|l|l|l|l|}
\hline \multirow{2}{*}{ No } & \multicolumn{2}{|c|}{ Intern } & \multicolumn{2}{c|}{ Ekstern } \\
\cline { 2 - 5 } & \multicolumn{1}{|c|}{ Strengths } & \multicolumn{1}{|c|}{ Weaksnesses } & Opportunities & \multicolumn{1}{c|}{ Threats } \\
\hline 1 & $\begin{array}{l}\text { Kemampuan hasil } \\
\text { produksi perikanan } \\
\text { yang cukup besar }\end{array}$ & $\begin{array}{l}\text { Produksi hasil } \\
\text { tangkapan yang } \\
\text { tidak menentu }\end{array}$ & $\begin{array}{l}\text { Produksi hasil } \\
\text { tangkapan } \\
\text { yang bervariasi }\end{array}$ & $\begin{array}{l}\text { Produksi hasil } \\
\text { tangkapan yang } \\
\text { mudah rusak }\end{array}$ \\
\hline 2 & $\begin{array}{l}\text { Melimpahnya } \\
\text { sumberdaya kelautan } \\
\text { dan perikanan }\end{array}$ & $\begin{array}{l}\text { Harga yang tidak } \\
\text { stabil }\end{array}$ & $\begin{array}{l}\text { Wilayah } \\
\text { pemasaran yang } \\
\text { luas }\end{array}$ & $\begin{array}{l}\text { Penetapan harga } \\
\text { secara sepihak }\end{array}$ \\
\hline 3 & $\begin{array}{l}\text { Letak wilayah yang } \\
\text { strategis }\end{array}$ & $\begin{array}{l}\text { Kelembagaan TPI } \\
\text { tempat pendaratan } \\
\text { Ikan yang tidak } \\
\text { berfungsi }\end{array}$ & $\begin{array}{l}\text { Kualitas hasil } \\
\text { tangkapan } \\
\text { yang segar }\end{array}$ & $\begin{array}{l}\text { Pengetahuan } \\
\text { masyarakat } \\
\text { tentang harga } \\
\text { yang } \\
\text { rendah }\end{array}$ \\
\hline 4 & $\begin{array}{l}\text { Lemasnas } \\
\text { pengetahuan proses } \\
\text { pemasaran }\end{array}$ & $\begin{array}{l}\text { Perkembangan } \\
\text { teknologi dalam } \\
\text { kegiatan } \\
\text { pemasaran yang } \\
\text { masih minim }\end{array}$ \\
\hline
\end{tabular}

Dari tabulasi tabel di atas, dapat diketahui bahwa setiap usaha/perusahaan termasuknya nelayan di Kabupaten Bengkalis, pasti dipengaruhi oleh beberapa faktor dalam menjalankan kegiatan pemasarannya. Faktor yang mempengaruhi tersebut meliputi kondisi, situasi, keadaan, dan peristiwa dan pengaruh-pengaruh yang berada di sekitar usaha/perusahaan yang memberikan pengaruh terhadap perkembangan usaha/perusahaan.

Menurut penulis, pemasaran merupakan ujung tombak dari setiap kegiatan usaha yang akan dijalankan. Produk yang baik dan berkualitas tidak akan 
memperoleh tingkat pendapatan yang maksimal apabila faktor pemasaran kurang baik dan tidak tepat sasaran

Pemasaran dalam suatu usaha memegang peranan penting dan perlu mendapatkan perhatian khusus. Pemasaran yang baik mampu mengidentifikasi kebutuhan konsumen, pengembangan produk, menetapkan harga yang tepat, mendistribusikan dan mempromosikan secara efektif, maka akan mudah penjual dalam menjual barangnya (Sula 2004).

\section{Saluran Distribusi Pemasaran Ikan Yang Ditempuh Nelayan Kabupaten Bengkalis}

Kegiatan pemasaran ikan-ikan hasil tangkapan oleh nelayan di Kabupeten Bengkalis tidak melalui Tempat Pendaratan Ikan (TPI) namun pada umumnya dilakukan langsung. Saluran distribusi pemasaran yang terbentuk terdiri dari 3 (tiga) saluran pemasaran. Saluran pemasaran ke satu dipasarkan langsung oleh nelayan yang dilakukan oleh istri nelayan ke konsumen akhir. Saluran pemasaran dua dipasarkan secara langsung ke pedagang pengumpul kemudian dipasarkan kembali ke pedagang pengecer dan didistribusikan ke konsumen akhir. Saluran pemasaran tiga dipasarkan secara langsung ke pedagang pengecer dan didistribusikan ke konsumen akhir.

Pedagang pengecer memiliki saluran pemasaran yang sangat pendek dibandingkan dengan pedagang pengumpul. Pedagang pengecer manyalurkan atau menjual langsung ikan kepada konsumen. Derah pemasaran ikan-ikan yang dijual pedagang pengecer adalah daerah Bengkalis dan sekitarnya. Pedagang pengumpul memiliki saluran pemasaran yang panjang yang mana menyalurkan ikan-ikan yang dibeli dari nelayan, yang terdapat dari luar Bengkalis. Pedagang pengumpul merupakan agen atau perwakilan pedagang besar. Dari pedagang-pedagang besar, ikan-ikan tersebut kemudian didistribusikan lagi kepada pedagang pengecer untuk kemudian dijual kepada konsumen akhir. Pedagang pengecer merupakan pedagang yang menjual langsung kepada konsumen. Terdapat 2 jenis pedagang pengecer yaitu pedagang pengecer yang menetap dan pedagang pengecer yang bergerak (mobile). Pedagang pengecer menetap umumnya melayani para konsumen biasanya warung-warung kecil/kedai. Sedangkan Pedagang pengecer bergerak merupakan pedagang yang melayani untuk konsumen penduduk lokal/sekitar kabupaten Bengkalis biasanya melakukan penjajaan keliling menggunakan sepeda motor.

Menurut penulis, pemasaran merupakan ujung tombak dari setiap kegiatan usaha yang akan dijalankan. Produk yang baik dan berkualitas tidak akan memperoleh tingkat pendapatan yang maksimal apabila faktor pemasaran kurang baik dan tidak tepat sasaran.

\section{Tinjauan Ekonomi Islam Terhadap Pemasaran Ikan di Kabupaten Bengkalis}

Berdasarkan hasil penelitian penulis di lapangan, pemasaran ikan yang ditempuh oleh nelayan di Kabupaten Bengkalis ada beberapa poin penting dalam melakukan kegiatan pemasaran yang berlandaskan pada nilai-nilai Islam, seperti: 
1. Salah satu kegiatan pemasaran ikan harus memperhatikan kualitas dan keberadaan ikan. Produksi yang dihasilkan harus mempunyai hubungan dengan kebutuhan hidup manusia dan bermanfaat untuk orang banyak dikarenakan sifat ikan yang gaib tidak bisa ditentukan jumlah produksi dan mudah rusak. Islam melarang jual-beli suatu produk yang belum jelas (gharar) bagi pembeli akan berpotensi terjadinya penipuan dan ketidak adilan terhadap salah satu pihak. Sabda Nabi: "Rasullullah melarang jual beli gharar (yang tidak jelas produknya)”(HR. Muslim dari Abu Hurairah)

2. Kegiatan pemasaran ikan yang dijual harus terang dan jelas kualitasnya, sehingga pembeli dapat dengan mudah memberi penilaian. Nelayan Tidak boleh menipu kualitas dengan jalan memperlihatkan yang baik bagian luarnya, dan menyembunyikan yang buruk pada bagian dalam. Dalam kegiatan pemasaran yang terpenting adalah kualitas ikan harus memenuhi standarisasi mutu. Bapak M.Bakri menjelaskan bahwa didalam proses pemasaran ikan yang diperoleh nelayan keadaan ikan masih dalam keadaan segar, karena ikan yang diperoleh langsung dipasarkan ke pedagang pengumpul. Kegiatan pemasaran yang dilakukan bapak M. Bakri sesuai dengan sabda Nabi saw: "Dari Abu Hurairah Radliyallaahu 'anhu bahwa Rasulullah Shallallaahu 'alaihi wa Sallam pernah melewati sebuah tumpukan makanan. Lalu beliau memasukkan tangannya ke dalam tumpukan tersebut dan jari-jarinya basah. Maka beliau bertanya: "Apa ini wahai penjual makanan?". Ia menjawab: Terkena hujan wahai Rasulullah. Beliau bersabda: "Mengapa tidak engkau letakkan di bagian atas makanan agar orang-orang dapat melihatnya? Barangsiapa menipu maka ia bukan termasuk golonganku." Riwayat Muslim. (Hidayat 2010)

3. Kegiatan pemasaran ikan yang terjadi memiliki proses penentuan harga. Mentukan harga ikan harus adil, penetuan harga ditentukan oleh mekanisme pasar, yakni bergantung pada kekuatan-kekuatan permintaan dan penawaran. Dan pertemuan antara permintaan dan penawaran itu harus berlangsung secara sukarela ('an taradhiin) ini bermakna tidak ada yang menganiaya dan dizalimi. Sebelum terjadi transaksi, idealnya nelayan dan pedagang pengumpul, pedagang pengecer dan konsumen harus berada pada posisi yang sama, baik menyangkut pengetahuan tentang barang maupun tentang harga yang berlaku di pasar. Sehingga ketika terjadi deal penjualan maupun pembeli betul-betul rela dan tidak ada yang teraniaya. Perintah tentang bersikap adil berulang-ulang disebut dalam Al-Qur'an. Diantaranya firman Allah swt. (QS, Al-Muthafifin (83): 1-6):

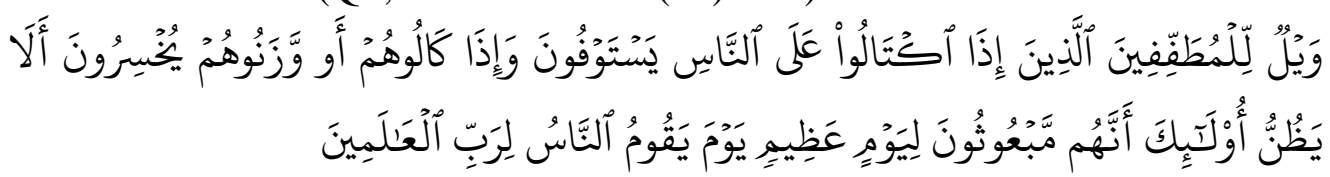

Artinya: Kecelakaan besarlah bagi orang-orang yang curang, (yaitu) orangorang yang apabila menerima takaran dari orang lain mereka minta dipenuhi,Dan apabila mereka menakar atau menimbang untuk orang lain, mereka mengurangi, Tidaklah orang-orang itu menyangka, bahwa Sesungguhnya mereka akan dibangkitkan, Pada suatu hari yang besar, (yaitu) hari (ketika) manusia berdiri menghadap Tuhan semesta alam.

4. Pemasaran yang baik dan benar adalah terhindar dari ikhtikar, yakni mengambil keuntungan diatas keuntungan normal dengan cara menjual 
lebih sedikit barang untuk harga yang lebih tinggi, atau istilah ekonominya monopoly's rent-seeking. Sabda Nabi: "tidaklah orang melakukan ikhtikar itu kecuali ia berdosa" (HR. Muslim, Ahmad, dan Abu Dawud). Nelayan dalam memasarkan hasil tangkapan yang diperoleh harus mengambil keuntungan yang wajar. Keuntungan dalam Islam menurut Ibnu Taimiyah merupakan motivasi para pedagang, menurutnya para pedagang berhak memperoleh keuntungan melalui cara-cara yang dapat diterima secara umum (al-rib.ai-ma'ruf) tanpa merusak kepentingan dirinya sendiri dan kepentingan para pelanggannya. Seperti firman Allah. (QS. Al- Baqarah (2): 275):

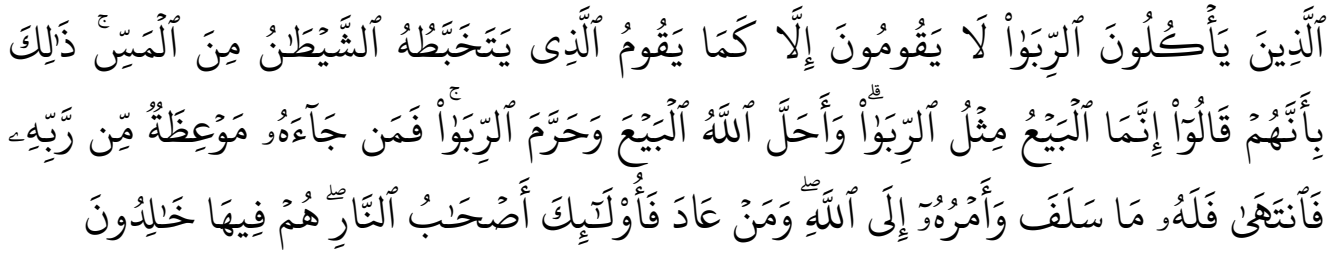

Artinya: Orang-orang yang Makan (mengambil) riba tidak dapat berdiri melainkan seperti berdirinya orang yang kemasukan syaitan lantaran (tekanan) penyakit gila. Keadaan mereka yang demikian itu, adalah disebabkan mereka berkata (berpendapat), Sesungguhnya jual beli itu sama dengan riba, Padahal Allah telah menghalalkan jual beli dan mengharamkan riba. orang-orang yang telah sampai kepadanya larangan dari Tuhannya, lalu terus berhenti (dari mengambil riba), Maka baginya apa yang telah diambilnya dahulu (sebelum datang larangan); dan urusannya (terserah) kepada Allah. orang yang kembali (mengambil riba), Maka orang itu adalah penghuni-penghuni neraka; mereka kekal di dalamnya. (QS. Al-Baqarah [2]: 275)

5. Dalam penetuan harga harus mengambil posisi tengah, tidak berlebihlebihan, tidak pula merendah-rendahkan. Ini berarti bahwa dalam praktik fiqh muamalah, pricing mestinya proporsional. Nabi Muhammad saw telah memberikan contoh ketika berdagang sebelum diangkat menjadi rasul. Saat menentukan harga, Nabi Muhammad saw hanya menyebut bahwa beliau membeli barang ini di Makkah 'sekian' dan perjalanan dari Makkah sampai Syam memerlukan 'sekian hari'. Kemudian Nabi Muhammad saw memberikan kebebasan bagi pembeli untuk memberi harga yang pantas terhadap baraang yang dijualnya. Kejujuran dan transparasi yang dipraktikan Nabi Muhammad saw ini ternyata membuahkan keuntungan yang luar biasa. Dalam rangka melindungi hak pembeli dan penjual, Islam membolehkan intervensi harga yang dilakukan oleh pemerintah.

6. Seorang nelayan tidak boleh mengenakan keuntungan yang lebih besar kepada orang yang tidak sadar dari pada yang dikenakan kepada oarang lain, dalam hal ini yang sama jika dia orang Islam yang butuh untuk membeli barang guna untuk memenuhi kebutuhan hidupnya yang berarti permintaan bersifat inelastis penjual harus menetapkan keuntungan yang sama dengan keuntungan yang diperoleh dari orang lain yang tak sebutuh orang tersebut. Keuntungan merupakan tambahan yang dihasilkan oleh tenaga dari satu pihak dan harta dipihak lain melalui pembagian keuntungan dilakukan dengan cara yang sama. Tujuan utama dari harga yang adil dan 
berbagai permasalahan yang terkait adalah untuk menegakan keadailan dalam transaksi, pertukaran dan hubungan lainya diantara masyarakat.

7. Penempatan barang adalah faktor vital dalam dunia usaha. Berkaitan erat dengan posisi ini adalah saran transportasi dan pengangkutan. Nabi Muhammad saw dengan tegas melarang pemotongan jalur distribusi dengan maksud untuk menaikan harga. Nabi Muhammad saw bersabda, "jangan membeli barang dari kafilah yang belum tiba di pasar, dan jangan membeli barang yang belum ada" (Muttafaq "Alaihi). Ini bisa dimaknai bahwa jangan pernah membeli dari penjual yang belum mengetahui harga pasar. Hal ini dimaksudkan untuk melindungi penjual dari penipuan mengenai harga yang sebenarnya.

8. Promosi dalam Islam yang dibenarkan adalah promosi yang mengandung nilai kejujuran, tranparan dan menjelaskan apa adanya. Didalamnya tidak terdapat unsur-unsur kebohongan dan penipuan baik segi kuatintas maupun kuantitas.Dalam melakukan promosi nelayan tidak diperbolehkan melakukan praktik penipuan mengenai hasil tangkapan yang dijual. Jujur dalam kualitas, kuantitas, timbangan dan takaran dalam menjelaskan kepada pembeli. Menerapakan perinsip jujur adalah harta yang peling berharga dalam melakukan kegiatan promosi. Mengenai jujur dalam takaran dan timbangan ini sesuai dengan firman Allah SWT dalam QS. Al-Muthafifin (83): 1-6.

9. Kejujuran dalam perdagangan dapat diwujudkan. misalnya, pedagang harus mengatakan dengan jujur bahwa barang yang dijualnya berkualitas baik tanpa ada campuran dengan barang kualitas buruk. Pedagang juga harus jujur dalam menakar, mengukur, dan menimbang (Mujahidin 2013).

Menurut pandangan penulis dalam melakukan pemasaran nelayan harus Shiddiq (benar dan jujur), dalam melakukan transaksi pemasaran diperlukan kejujuran antara nelayan dengan pedagang pengumpul, pedagang pengecer maupun konsumen berkenaan dengan hasil tangkapan yang diperoleh nelayan harus menjelaskan kondisi kesegaran hasil tangkapan yang diperoleh.

Saluran distribusi pemasaran dalam Islam sangat memperhatikan bagaimana saluran pemasaran yang baik disamping mengingat Allah SWT, selanjutnya seorang marketing dalam kegiatan pemasarannya harus menunjukkan keistimewaan-keistimewaannya dan kelemahan-kelemahan dari produknya, dan menggunakan sistem promosi yang jujur agar pihak lain tertarik membelinya tanpa harus melakukan dengan berbuat yang tidak baik.

Rasulullah saw. adalah orang yang mengeluti dunia perdagangan, sekaligus seorang pemasar (marketer) yang andal. berpegang kejujur, suatu sifat yang sudah melekat pada diri Rasullah saw. kejujuran ini diiringi dengan ikhlas, dimana dengan keikhlasan seorang pemasar tidak akan mengejar materi belaka.

Nelayan harus amanah, artinya nelayan dalam melakukakan pemasaran hasil tangkapan memiliki sifat amanah yang mana dapat dipercaya, bertanggung jawab dan kredibel dalam memenuhi keinginan untuk memperoleh keuntungan sesuai ketentuan dalam ajaran Islam

Nelayan harus memiliki kecerdasan (Fathanah), dalam memahami kebutuhan dan keinginan konsumen dalam memasarkan hasil tangkapan yaang diperoleh secara mendalam segala hal yang menjadi tugas dan kewajiban 
nelayan. Pemasaran hasil tangkapan nelayan harus memiliki prinsip kerelaan antar kedua belah pihak yaitu nelayan dan pedagang pengumpul, pedagang pengecer dan konsumen dalam berinteraksi.

Dalam melakukan proses pemasaran tidak boleh saling menzalimi dan terzolimi yang bertentangan dengan ajaran Islam yaitu: Garar (tidak jelas) dalam hal penetapan harga hasil tangkapan harus berlandaskan keadilan yang mana harga yang ditetapakan oleh produsen maupun pedagang pengumpul harus saling menguntungkan dan tidak menzolimi. Pada kenyatannya harga hasil tangkapan yang dibeli oleh pedagang ditetapkan sepihak tanpa memperhitungkan masalah yang dihadapi oleh nelayan. Kegiatan pemasaran sangat dilarang adanya unsur riba, yang mana nelayan dalam menjual hasil tangkapan harus mejauhi transaksi yang memiliki unsur-unsur riba seperti: Riba fadl, riba nasi'ah, riba Jahiliyah.

\section{KESIMPULAN}

Berdasarkan hasil penelitian yang dilakukan maka diperoleh beberapa kesimpulan penelitian sebagai berikut:

1. Faktor Internal meliputi; kekuatan dan kelemahan. a. Kekuatan yaitu, Kemampuan hasil produksi perikanan yang cukup besar, Melimpahnya sumberdaya kelautan dan perikanan, dan letak wilayah yang strategis. b. kelemahan yaitu, produksi hasil tangkapan yang tidak menentu, harga yang tidak setabil, kelembagaan TPI (tempat pendaratan ikan) yang tidak berfungsi, dan lemahnya pengetahuan pemasaran. Dan faktor eksternal meliputi peluang dan ancaman; a. Peluang yaitu, produksi hasil tangkapan yang bervariasi, wilayah pemasaran yang luas, dan kualitas hasil tangkapan yang segar. b. Ancaman yaitu, produksi hasil tangkapan yang mudah rusak, penetapan harga secara sepihak, pengetahuan masyarakat tentang harga yang masih rendah, dan perkembangan teknologi dalam pemasaran yang masih minim.

2. Saluran distribusi pemasaran ikan yang ditempuh nelayan Kabupaten Bengkalis pada empat wilayah penelitian khususnya kecamatan Bengkalis, Kecamatan Bantan, Kecamatan Rupat dan Kecamatan Rupat utara beragam bentuk sistem pemasaran yang dilakukan antara lain:

a. Nelayan memasarkan langsung kepada consumen

b. Nelayan memasarkan langsung ke pedagang pengumpul kemudian dipasarkan kembali ke pedagang pengecer baru didistribusikan kepada konsumen akhir.

c. Nelayan memasarkan langsung ke pedagang pengecer dan distribusikan langsung kepada konsumen akhir.

3. Tinjauan ekonomi Islam terhadap pemasaran ikan yang terjadi di Kabupaten Bengkalis belum memenuhi nilai-nilai dan prinsip Islam dalam pelaksanaan pemasaran berkaitan dengan jumlah hasil tangkapan (produksi), penetapan harga, tempat memasarkan ikan dan cara mempromosikan hasil tangkapan masih banyak kekurangan serta ada unsur gharar, Iktikar, spekulatif dan unsur menzolimi. 


\section{DAFTAR PUSTAKA}

Arifin, Muhammad bin Badri. 2008. Sifat Perniagaan Nabi SAW. Bogor: Pustaka Darul Ilmi.

Departemen Agama RI. 2009. Al-Quran dan Terjemahannya. Bandung: PT Sygma Examedia Arkanleema.

Fauzi, Akhmad. 2010. Ekonomi Perikanan. Jakarta: Gramedia Pustaka Utama.

Hidayat, Dani. 2010. Bulughul Maram Min Adillatil Ahkaam, Al-Hafidz Imam Ibnu Hajar Al- Asqalany, Versi.3.01. Tasikmalaya.

Kartajaya, Herman dan Sula, Muhammad Syakir. 2006. Syariah Marketing, Bandung: PT. Mizan Pustaka.

Mubyarto. 1995. Pengantar Ekonomi Pertanian. Jakarta: LP3ES.

Mujahidin, Akhmad. 2013, Ekonomi Islam, Sejarah, Konsep, Instrumen, Negara, dan Pasar. Jakarta: PT. Raja Grafindo Persada.

Ridwan, Ahmad Hasan. 2004. BMT dan Bank Islam. Bandung: Pustaka Bani Quraisy.

Stanton, W.J. 1996. Prinsip Pemasaran Terjemahaan. Jakarta: Erlangga.

Sujarno, 2008. "Analisis Faktor-Faktor Yang Mempengaruhi Pendapatan Nelayan Di Kabupaten Langkat". Thesis (Medan: Universitas Sumatra Utara) diakses dari repository.usu.ac.id/bitstream/123456789/7165/ 1/09E00282. pdf pada tanggal 1 Januari 2016 Pukul 11.00.

Sula, Muhammad Syakir. 2004. Asuransi Syariah. Jakarta: Gema Insani.

Anwar, Khairil. 2011. http://khairilanwarsemsi.blogspot.com. 